\title{
The spatio-temporal variability of groundwater storage in the Amazon River Basin
}

\author{
F. Frappart ${ }^{\mathrm{b}, *}$, F. Papa ${ }^{\mathrm{b}, \mathrm{c}}$, A. Güntner ${ }^{\mathrm{d}}$, J. Tomasella ${ }^{\mathrm{e}}$, J. Pfeffer ${ }^{\mathrm{f}}$, G. Ramillien ${ }^{\mathrm{a}}$, T. Emilio ${ }^{\mathrm{g}, \mathrm{l}}$, \\ J. Schietti ${ }^{\text {h }}$, L. Seoane ${ }^{a}$, J. da Silva Carvalho ${ }^{i}$, D. Medeiros Moreira ${ }^{j}$, M.-P. Bonnet ${ }^{k}$, F. Seyler $^{k}$ \\ ${ }^{a}$ Géosciences Environnement Toulouse (GET), UMR 5563, CNRS/IRD/UPS, Observatoire Midi-Pyrénées (OMP), 14 Avenue Edouard Belin, 31400 Toulouse, France \\ ${ }^{\mathrm{b}}$ Laboratoire d'Etudes en Géophysique et Océanographie Spatiales (LEGOS), UMR 5566, CNRS/IRD/UPS, Observatoire Midi-Pyrénées (OMP), 14 Avenue Edouard \\ Belin, 31400 Toulouse, France \\ ' IFCWS, IRD-IISc Joint International Laboratory, Indian Institute of Science, 560012 Bangalore, India \\ ${ }^{\mathrm{d}}$ Deutsches GeoForschungsZentrum (GFZ), Telegrafenberg, Potsdam, Germany \\ ${ }^{\mathrm{e}}$ Centro Nacional de Monitoramento e Alerta de Desastres Naturais - CEMADEN. Rodovia Presidente Dutra km 39, 12630-000 Cachoeira Paulista, SP, Brazil \\ ${ }^{\mathrm{f}}$ Research School of Earth Sciences, Australian National University, Canberra, Australian Capital Territory, Australia \\ ${ }^{g}$ Comparative Plant \& Fungal Biology, Royal Botanic Gardens, Kew, Richmond, Surrey, UK \\ ${ }^{\mathrm{h}}$ Instituto Nacional de Pesquisas da Amazônia (INPA), Manaus, AM, Brazil \\ ${ }^{\mathrm{i}}$ Universidade Federal do Manaus (UFAM), Manaus, AM, Brazil \\ j CPRM/Geological Survey of Brazil, Rio de Janeiro, Brazil \\ ${ }^{\mathrm{k}}$ IRD, UMR Espace-Dev, Maison de la télédétection, 500 rue JF Breton, 34093 Montpellier Cedex 5, France \\ ${ }^{1}$ Department of Plant Biology, Institute of Biology, University of Campinas, CEP 13083-970, Campinas, SP, Brazil
}

\section{A R T I C L E I N F O}

\section{Keywords:}

Groundwater

Amazon

Multisatellite

Hydrological models

\begin{abstract}
A B S T R A C T
In large Tropical River basins such as the Amazon, groundwater plays a major role in the water and ecological cycles with large influences on the rainforest ecosystems and climate variability. However, due to the lack of monitoring networks, Amazon groundwater storage and its variability remain poorly known. Here, we provide an unprecedented direct estimate of the spatio-temporal variations of the anomaly of groundwater storage over the period January 2003 -September 2010 in the Amazon Basin by decomposing the total terrestrial water storage measured by the Gravity Recovery and Climate Experiment (GRACE) mission into the individual contributions of other hydrological reservoirs, using multi-satellite data for the surface waters and floodplains and models outputs for the soil moisture. We show that the seasonal variations of groundwater storage represent between 20 and $35 \%$ of the terrestrial water storage seasonal volume variations of the Amazon. Larger seasonal amplitudes of groundwater storage $(>450 \mathrm{~mm})$ are found in the Alter do Chão and Iça aquifers in the central part of the Amazon Basin. Anomalies of groundwater storage exhibit a strong interannual variability (STD reaching $120 \mathrm{~mm}$ along the central corridor) during the study period in response to hydrologic variability and climatic events such as the extreme drought that occurred in 2005.
\end{abstract}

\section{Introduction}

Being the largest reservoir of freshwater on Earth, accounting for more than $30 \%$ (i.e., $8,000,000$ to $10,000,000 \mathrm{~km}^{3}$ ) of global freshwater resources, groundwater plays a key role in the terrestrial hydrological cycle and in sustaining ecosystems (Taylor et al, 2013). It is also the major resource of freshwater supply for $40 \%$ of the world population and $50 \%$ of the world food production (Seiler and Gat, 2007; Margat and van der Gun, 2013), becoming a strategic importance for global water and food security under global change. In the Amazon basin, the world's largest river system, groundwater storage plays a central part in the ecological cycles and directly influences the rainforest ecosystems as well as climate variability (Pokhrel et al., 2013). Strong memory effects of Amazon groundwater system even convey climate anomalies over the region for several years (Tomasella et al., 2008; Pfeffer et al., 2014).

However, groundwater storage and its variations are still poorly known at large to global scales due to the limited extent and capability of current monitoring networks and the difficulty to survey large and remote areas. In the Amazon, most studies on hydrogeology of groundwater reservoirs are carried out only at local (Do Nascimento et al., 2008; Tomasella et al., 2008) to regional scales (Pimentel and Hamza, 2012; Pfeffer et al., 2014) limiting our understanding of the role of groundwa-

\footnotetext{
* Corresponding author at: Géosciences Environnement Toulouse (GET), UMR 5563, CNRS/IRD/UPS, Observatoire Midi-Pyrénées (OMP), 14 Avenue Edouard Belin, 31400 Toulouse, France.

E-mail address: frederic.frappart@legos.obs-mip.fr (F. Frappart).
} 
a)

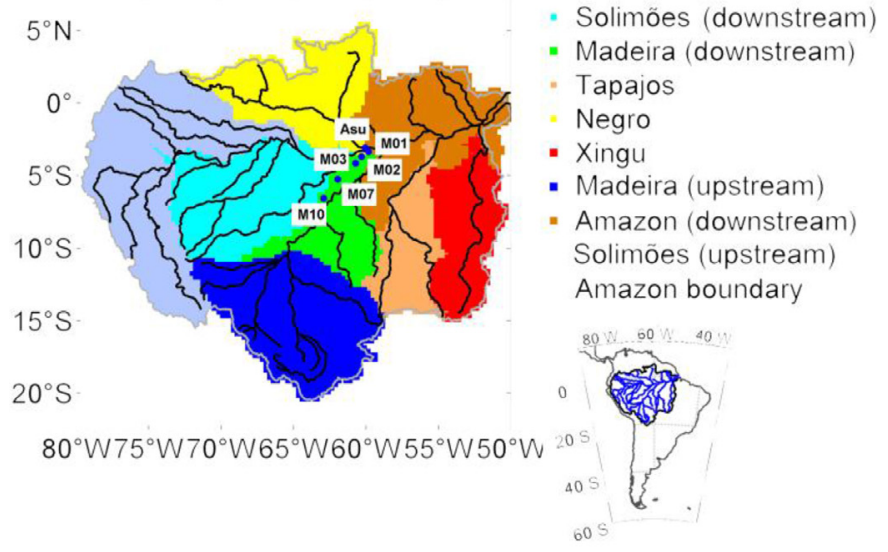

b)

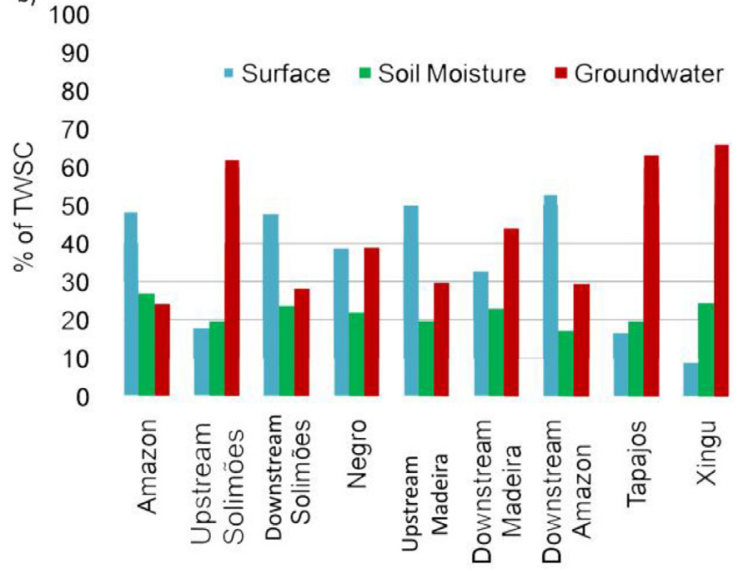

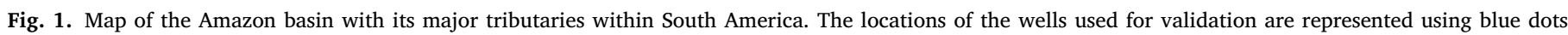

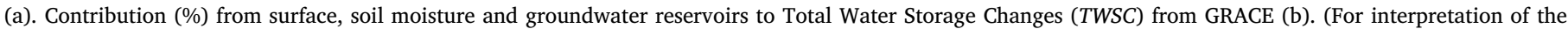
references to color in this figure legend, the reader is referred to the web version of this article.)

ter in the terrestrial water cycle. Only recently the influence of groundwater on terrestrial water storage in the Amazon Basin was characterized in an integrative model-based study of the groundwater for the entire basin (Miguez-Macho and Fan, 2012; Pokhrel et al., 2013).

In this context, remote sensing techniques offer a unique opportunity for hydrologic investigations (Alsdorf et al., 2007; Rast et al., 2014) and recent advances have demonstrated that water resources can be monitored reliably from space. In particular, the Gravity Recovery And Climate Experiment (GRACE) mission, launched in 2002, detects tiny changes in the Earth's gravity field, which can be related to spatio-temporal variations of terrestrial water storage at monthly or sub-monthly time-scales (Tapley et al., 2004). Analysis of GRACE data showed that the frequent extreme climatic events that occurred in the Amazon Basin since mid-2000 (e.g., droughts of 2005 and 2010 droughts, flood of 2009) had a strong impact on terrestrial water storage (Chen et al., 2009; 2010; Frappart et al., 2013a,b; Espinoza et al., 2013). If their signatures on surface water storage were widely described (e.g., Marengo et al., 2008, 2011; Tomasella et al., 2011; Frappart et al., 2012), their consequences on groundwater remain poorly known. Variations in groundwater storage can be separated from the terrestrial water storage anomalies measured by GRACE (see Frappart and Ramillien, 2018 for a review on the use of GRACE for groundwater monitoring) using external information on the other hydrological stores (snow and ice, soil moisture and surface water) from in situ (Yeh et al., 2006) and satellite (Tian et al., 2017) observations, model outputs (Roddel et al., 2009; Jin and Feng, 2013), or both (Leblanc et al., 2009). Very few studies (e.g., Frappart et al., 2011; Shamsudduha et al., 2012) have been conducted yet in large river basins characterized by extensive wetlands and floodplains, due to the lack of reliable and timely information on the spatio-temporal distribution of the extent and storage of surface waters. In these basins, surface water stored in floodplains represents a large part of the terrestrial water storage (e.g., $~ 50 \%$ of the water stored and $15-20 \%$ of the water that flowed out of the Amazon Basin between 2003-2007 was stored in the Amazon floodplains (Frappart et al., 2012; Papa et al., 2013). In spite of recent advances, the capability of global hydrological models to simulate water storage in large floodplains are still limited due to the lack of availability and accuracy of data as the digital elevation model and computational expense (Lehner and Grill, 2013; Sampson et al., 2015). To overcome this limitation, our approach takes into account the water stored in the surface reservoir using water level maps obtained by combining satellite altimetry and imagery. Using multi-satellite observations along with hydrological modeling, we estimate the contribution of each hydrological reservoir of the Amazon basin (surface water, soil moisture and groundwater) to terrestrial water storage variations and map, for the first time, the seasonal changes of freshwater stored in the Amazon aquifers over the period January 2003 - September 2010. We show that the exceptional drought of 2005 had a large impact on groundwater storage.

\section{Datasets}

To estimate groundwater ( $G W$ ) storage anomalies, the contribution of surface and soil moisture storages are removed from the terrestrial water storage (see Section 3). The data used for this purpose are multisatellite surface water ( $S W$ ) levels maps, soil moisture $(S M)$ from WaterGAP Global Hydrology Model, terrestrial water storage (TWS) from GRACE land water solutions processed with a regional approach. Ancillary data (i.e., in situ groundwater levels and groundwater storage from two global hydrological models) were also used for comparison and validation of the results.

\subsection{The multisatellite surface water level and storage maps}

Maps of water levels over the floodplains of the Amazon Basin were obtained by combining observations from a multisatellite inundation dataset and altimetry-based water levels at monthly time-scale from January 2003 to September 2010. The approach used is the same as the one presented in (Frappart et al., 2012) but using a monthly climatology for the surface water extent from the Global Inundation Extent MultiSatellite (GIEMS) as this dataset is available only from January 1993 to December 2007 (Papa et al., 2010; Prigent et al., 2007, 2012). Water levels from 984 ENVISAT RA-2 altimetry stations made available by Hydroweb (http://hydroweb.theia-land.fr) (Santos da Silva et al., 2010; Normandin et al., 2018) were interpolated with respect to the inverse of the distance to the gridpoint over inundated surfaces from GIEMS monthly climatology. Each monthly map of surface water levels has a spatial resolution of $0.25^{\circ}$ and is referenced to EGM2008 geoid. Time variations of $S W$ volume over the entire Amazon Basin for 1) the estimates from Frappart et al. (2012) using monthly GIEMS inundation extent over 2003-2007 and 534 altimetry-based water levels (called C1), 2 ) the estimates obtained using monthly GIEMS inundation extent over 2003-2007 and 984 altimetry-based water levels from Hydroweb (C2) and 3) the estimates obtained using monthly GIEMS climatology of inundation extent and 984 altimetry-based water levels from Hydroweb (C3) are presented in Fig. S1. They show very similar behavior, with biases of -55 and $-32 \mathrm{~km}^{3}$, RMSE of 23 and $31 \mathrm{~km}^{3}$, (to be compared with an annual amplitude of $>1000 \mathrm{~km}^{3}$ ), and correlation coefficients 

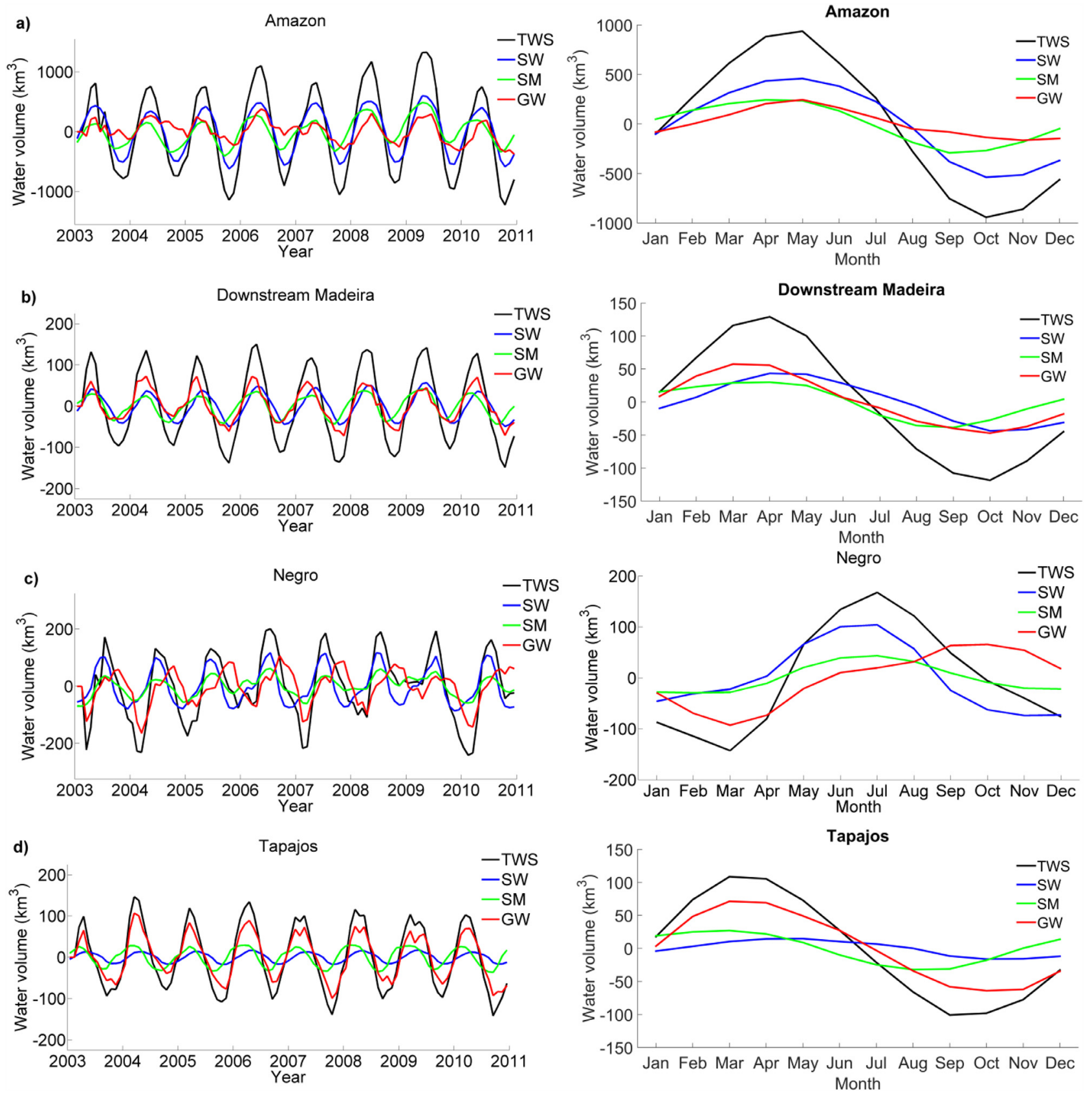

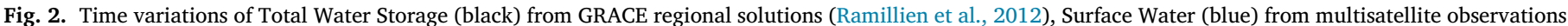

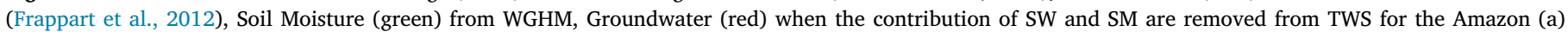

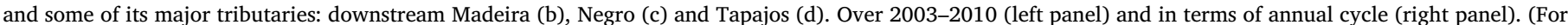
interpretation of the references to color in this figure legend, the reader is referred to the web version of this article.)

of 0.997 and 0.998 found between C2 and C1 and C2 and C3 respectively. These results confirm that the use of GIEMS monthly climatology in order to retrieve time-series of $S W$ volume over the whole period of availability of the ENVISAT data provides acceptable estimates. The error on these estimates is lower than $17 \%$ (see supplementary information for details on the error estimates). A map of minimum water levels was estimated for the entire observation period using a hypsometric approach to take into account the difference of altitude between the river and the floodplain (see Frappart et al., 2012 for more details). This dataset is made available by Centre de Topographie des Océans et de l'Hydrosphère (CTOH): http://ctoh.legos.obs-mip.fr.

\subsection{WGHM and ISBA-TRIP hydrological model outputs}

The WaterGAP Global Hydrology Model (WGHM) is one of the most commonly used water balance model for the assessment of water resources and water balances in large river basins. WGHM accounts for all main continental water storage components including groundwater, soil moisture, snow, canopy storage, and surface waters in lakes, rivers, wetlands, and reservoirs. In this study, WGHM in the version STANDARD within WaterGAP2.2 as described in Müller Schmied et al. (2014) was applied. For model calibration against observed river discharge time series, 1319 gauging stations worldwide, made available by Global Runoff Data Centre (GRDC) in Koblenz, Germany (http://grdc.bafg.de), are 


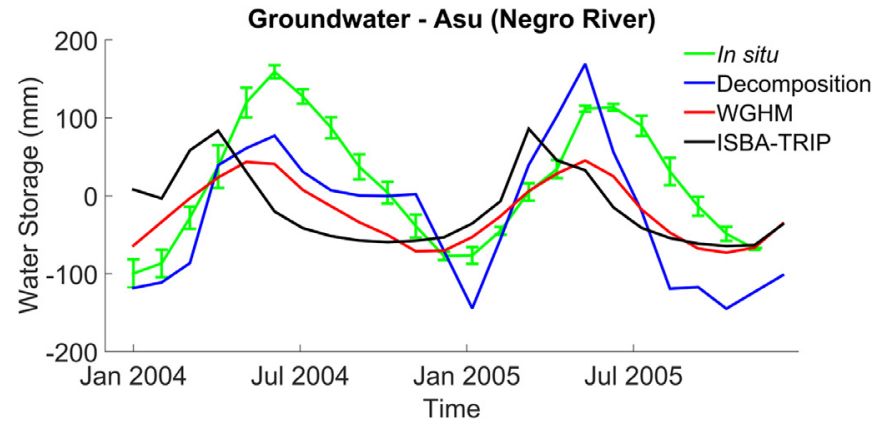

Fig 3. Anomaly of groundwater storage from well measurements (green), the decomposition method (blue), WGHM (red) and ISBA-TRIP (black) model outputs at Asu catchment (Negro River). (For interpretation of the references to color in this figure legend, the reader is referred to the web version of this article.)

used in WGHM. Simulated water storage of $S M$ and $G W$ is provided with $0.5^{\circ}$ of spatial resolution at daily or monthly time-scales. In this study, we use the monthly SM and GW outputs from WGHM over 20032010 for estimating the GW component and comparison purpose respectively. For evaluation purposes, we also used the simulated storage of the $S M$ and $G W$ reservoirs from the ISBA-TRIP model (Alkama et al., 2010; Decharme et al., 2010).

\subsection{GRACE-derived land water mass solutions}

The Gravity Recovery And Climate Experiment (GRACE) mission, launched in March 2002, provides measurements of the spatio-temporal changes in Earth's gravity field (Tapley et al., 2004). Several recent studies have shown that GRACE data over the continents can be used to derive the monthly changes of the total land water storage with an accuracy of $\sim 1.5 \mathrm{~cm}$ of equivalent water thickness when averaged over surfaces of a few hundred square-kilometres (see Frappart et al., 2016 for a recent review). In this study, we used maps of equivalent water height derived from GRACE measurements using a regional approach (Ramillien et al., 2011, 2012). This new strategy is based on the optimal localization in space, instead of the best localization in spatial frequency, and leads theoretically to better spatial localization and resolution (see Freeden and Schreiner, 2008). Ramillien et al. (2012) demonstrated that this regional method offers a reduction of north-south striping due to both the distribution of GRACE satellite tracks and the temporal aliasing of correcting models that are present in the global GRACE solutions over South America (Frappart et al., 2013a), Australia (Seoane et al., 2013), and Africa (Ramillien et al., 2014). According to these three latter studies, regional maps present more realistic spatial and temporal patterns than the global solutions when compared to independent datasets of rainfall, water levels and discharges, wetlands locations.

\subsection{Masks of the sub-basin}

Masks at $0.25^{\circ}$ of spatial resolution of the largest sub-basins of the Amazon were built using the watershed delineation for the Amazon sub-basin systems based on GTOPO30 DEM and a drainage network extracted from JERS SAR images from Seyler et al., (2009). The Amazon drainage system was decomposed into 8 large drainage areas (larger than $400,000 \mathrm{~km}^{2}$ to be compatible with the low spatial resolution of the GRACE data, see Frappart et al., 2013b): upstream Solimões encompassing Ucayali and Marañon flowing from the south, and the Japura and the Iça flowing from northwest, downstream Solimões, upstream Madeira, downstream Madeira, Negro, downstream Amazon, Tapajos, and Xingu basins.

\subsection{In situ groundwater levels}

Groundwater levels are monitored in situ using wells. In the region north of Manaus, PVC $15 \mathrm{~cm}$ diameter dipwells were installed at depth varying from 30 to $50 \mathrm{~m}$, as described by Tomasella et al., (2008) and Carvalho (2012). Along the Purus-Madeira transect, water level were monitored using PVC tubes ( $3 \mathrm{~cm}$ diameter) installed at a maximum depth of $7 \mathrm{~m}$. All wells were monitored manually. Groundwater levels were recorded in situ from January 2004 to November 2005 and from August 2010 to May 2011 at Asu catchment, and from September 2011 to December 2012 at the other measurement sites. The conversion from well depths to GW variations is performed using specific yield values $\left(S_{y}\right)$ of 0.17 in the Asu catchment (Tomasella et al., 2008) and of 0.1 elsewhere. Their locations, altitude and the $S_{y}$ are given in Table S1.

\subsection{Altimetry-based groundwater table maps}

The annual fluctuations of the groundwater base-level (GWBL) were derived from the analysis of ENVISAT - satellite radar altimetry measurements acquired from late 2002 to mid-2009 across the central Amazon basin (Pfeffer et al., 2014). The GWBL is the minimum height reached each year by the GW table during low water periods, when the GW table is connected to the water levels in rivers, lakes and floodplains (Fig. 1 from Pfeffer et al., 2014). The GWBL is obtained through the interpolation of the annual minima identified in the ENVISAT time-series extracted from 491 VS located along rivers, lakes and floodplains of the central Amazon [Pfeffer et al., 2014]. The GWBL maps acquired from 2003 to 2008 were validated against in situ observations of the groundwater table depth (Fan et al., 2013) and hydrological model outputs (Pfeffer et al., 2014). The GWBL data are available online at: https://julia-pfeffer.weebly.com/data.html. In the following, we will use GWBL anomalies, defined as the difference between he GWBL for a given year and the average GWBL computed over the 2003-2008 timeperiod. The mean GWBL anomaly is indeed mostly representative of the spatial variations of the GWBL, forming a continuous drainage structure strongly driven by surface topography, while the GWBL anomaly highlights the fluctuations of the GWBL in time (Pfeffer et al., 2014).

\subsection{TRMM monthly rainfall}

Tropical Rainfall Measuring Mission (TRMM) 3B43 v7 product is a combination of satellite information from the passive microwave imager (TMI) and precipitation radar (PR) onboard TRMM, a JapanUnited States satellite launched in November 1997, the Visible and Infrared Scanner (VIRS) onboard the Special Sensor Microwave Imager (SSM/I) and rain gauge observations. The TRMM 3B43v7 product merges the TRMM 3B42-adjusted infrared precipitation with the monthly-accumulated Climate Assessment Monitoring System or Global Precipitation Climatology Center Rain Gauge analyses (Huffmann et al., $1995,2007)$. It has a spatial resolution of $0.25^{\circ}$ and a temporal resolution of one month. It is available on the Goddard Earth Sciences Data and Information Services Center (GES DISC) website: http://disc.sci.gsfc.nasa.gov/. In this study, data from 2003 to 2010 were used.

\section{Methods}

\subsection{Groundwater storage estimates using a decomposition method}

TWS is the sum of the contributions of the different storage compartments:

$\Delta T W S=\Delta S W+\Delta S M+\Delta G W$

where $S W$ represents the total surface water storage including lakes, reservoirs, in-channel and floodplains water; $S M$ is the soil moisture, $G W$ is the groundwater storage in the aquifers. More specifically, $S M$ 

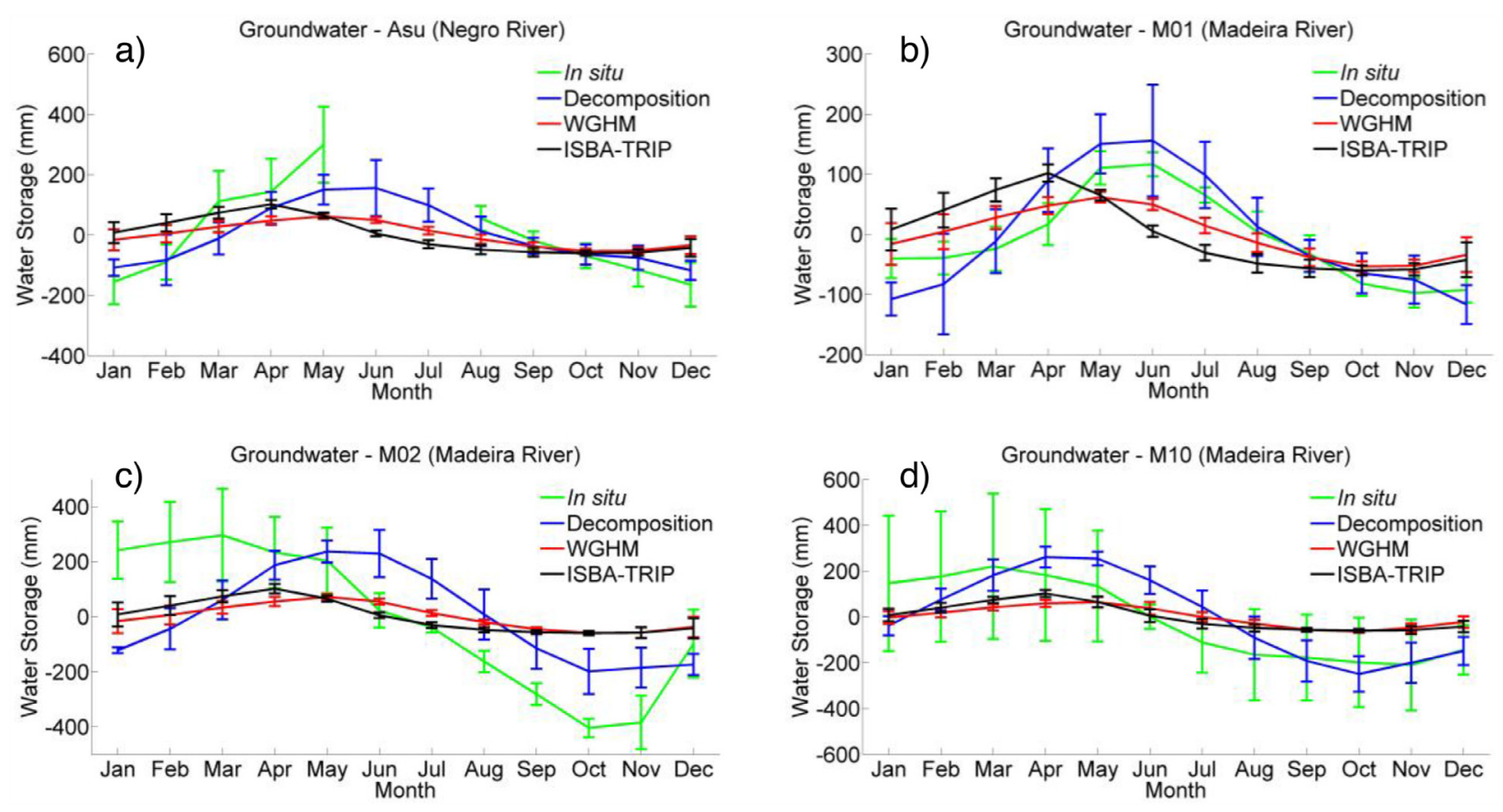

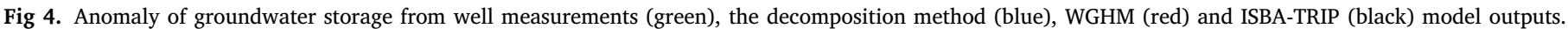

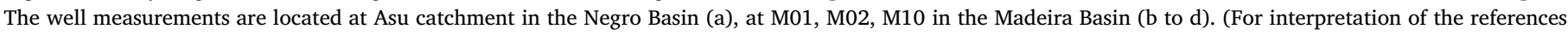
to color in this figure legend, the reader is referred to the web version of this article.)

in our study is defined as the water content in the root zone as represented by the WaterGAP Global Hydrology Model. Root depth in this model is dependent on the land cover type with a maximum rooting depth of $4 \mathrm{~m}$ (Müller Schmied et al., 2014). Thus, when solving Eq. (1) for $G W$, this latter component may comprise water storage in the unsaturated zone below the rooting depth in the case of deeper groundwater bodies. Because of their small contributions, we neglect here the variations of canopy storage and snow storage. The storage terms are generally expressed in volume $\left(\mathrm{km}^{3}\right)$ or $\mathrm{mm}$ of equivalent water height. $G W$ monthly storage anomalies at $1^{\circ}$ of spatial resolution were computed using Eq. (1) over 2003-2010, the period of overlap of all the datasets. TWS monthly anomalies at $2^{\circ}$ of spatial resolution come from regional solutions computed over South America (Ramillien et al., 2012, see Section 2.3), $S W$ from monthly $S W$ level maps at $0.25^{\circ}$ of spatial resolution obtained as the combination of GIEMS and altimetry-based water levels from ENVISAT RA-2 (see 2.1), SM from WGHM monthly outputs at $0.5^{\circ}$ of spatial resolution (see Section 2.2). This direct resolution of Eq. 1 will be referred in the followings as the decomposition method. Using Eq. (1), the error on $G W$ storage variations $\left(\sigma_{G W}\right)$ can be expressed as a function of the error on TWS $\left(\sigma_{T W S}\right)$, SW $\left(\sigma_{S W}\right)$ and SM $\left(\sigma_{S M}\right)$ (see Frappart and Ramillien, 2018):

$\sigma_{G W}=\sqrt{\left(\sigma_{T W S}\right)^{2}+\left(\sigma_{S W}\right)^{2}+\left(\sigma_{S M}\right)^{2}}$

\subsection{Time series of water volume variations}

At basin scale, the time-variations of surface water volume is simply computed as in Frappart et al. (2012, 2015):

$$
\begin{aligned}
V_{S W}(t)= & R_{e}^{2} \sum_{j \in S} P\left(\lambda_{j}, \varphi_{j}, t\right)\left(h\left(\lambda_{j}, \varphi_{j}, t\right)\right. \\
& \left.-h_{\min }\left(\lambda_{j}, \varphi_{j}, P\left(\lambda_{j}, \varphi_{j}, t\right)\right)\right) \cos \left(\varphi_{j}\right) \Delta \lambda \Delta \varphi
\end{aligned}
$$

where $V_{S W}$ is the volume of surface water, $R_{e}$ the radius of the Earth equals $6378 \mathrm{~km}, P\left(\lambda_{j}, \varphi_{j}, t\right), h\left(\lambda_{j}, \varphi_{j}, t\right), h_{\min }\left(\lambda_{j}, \varphi_{j}\right)$ are respectively the percentage of inundation, and the water level at time $t$, the minimum of water level of the pixel of coordinates $\left(\lambda_{j}, \varphi_{j}\right), \Delta \lambda$ and $\Delta \varphi$ are respectively the grid steps in longitude and latitude. The minimum water level was determined using a hypsometric approach relating the percentage of inundation of a pixel to its elevation (see the supplementary information from Frappart et al. (2012) available at stacks.iop.org/ERL/7/044010/mmedia for more details).

Accordingly, the time variations of volume of TWS and SM $\left(V_{T W S / S M}(t)\right)$ anomalies are computed following Ramillien et al. (2005):

$\Delta V_{T W S / S M}(t)=R_{e}^{2} \sum_{j \in S} \Delta h_{T W S / S M}\left(\lambda_{j}, \varphi_{j}, t\right) \cos \left(\varphi_{j}\right) \Delta \lambda \Delta \varphi$

where $h_{T W S / S M}\left(\lambda_{j}, \varphi_{j}, t\right)$ is the anomaly of TWS or $S M$ at time $t$ of the pixel of coordinates $\left(\lambda_{j}, \varphi_{j}\right)$.

\subsection{The contributions of hydrological reservoirs to TWS}

The contribution of each hydrological component $\left(C T W S_{H R}\right)$ to TWS (i.e., $S W, S M$, and $G W$ ) is computed for each sub-basin as the ratio between the change in each hydrological reservoir and the change in TWS:

$C T W S_{H R}=\frac{\max \left(S_{H R}\right)-\min \left(S_{H R}\right)}{\max (T W S)-\min (T W S)}$

The changes in each hydrological reservoir $\left(S_{H R}\right)$ and in TWS are obtained as the difference between the seasonal extrema values averaged over the observation period (2003-2007). To smooth out possible outliers, the seasonal extrema are averaged over the range 85 to $100 \%$ of seasonal change.

\section{Results}

A continuous mapping of groundwater storage at $1^{\circ}$ of spatial resolution in the Amazon basin and for each of its major sub-basins (see Fig. 1a for their locations) is presented at monthly time-scale over the January 2003-September 2010 time-period in Fig. S2. Fig. 1b presents the contribution of each hydrological reservoir to TWS for eight major sub-basins of the Amazon (see Hydrological reservoirs contribution to TWS in section Methods). For the whole Amazon basin, SW, SM and 
a) minimum GW anomaly 2003

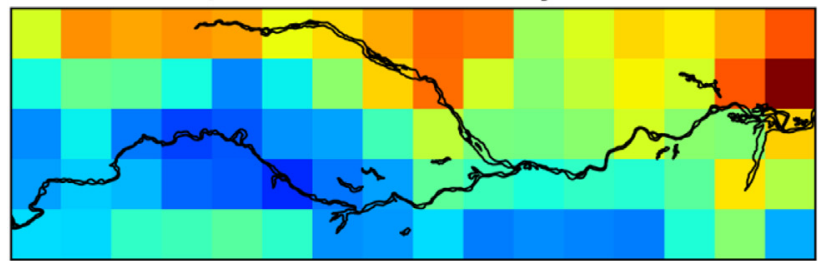

c) minimum GW anomaly 2004

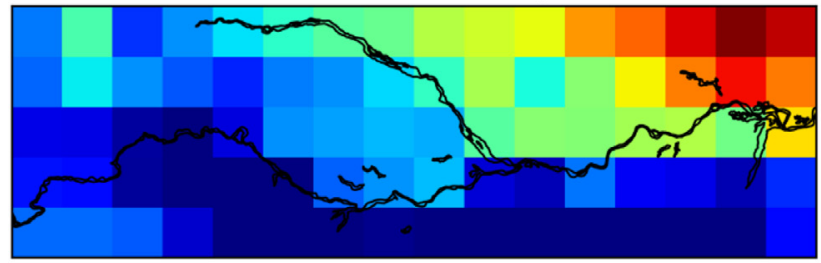

e) minimum GW anomaly 2005

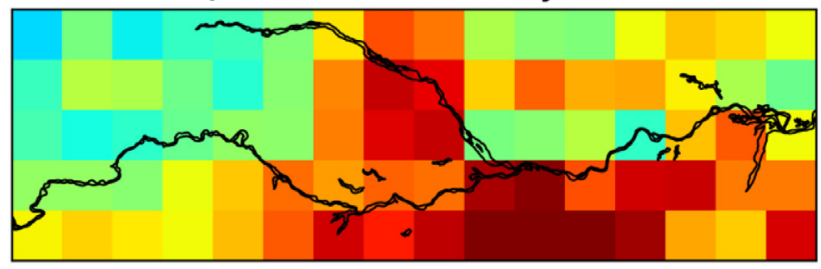

g) minimum GW anomaly 2006

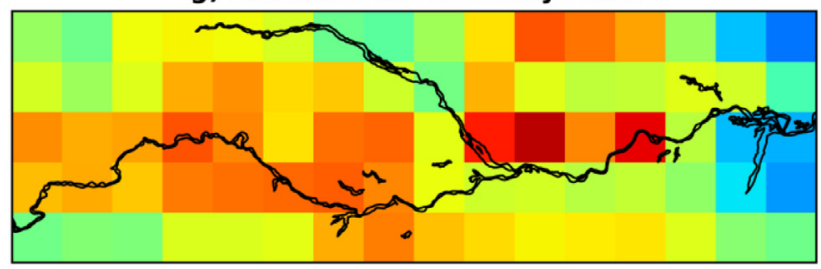

i) minimum GW anomaly 2007

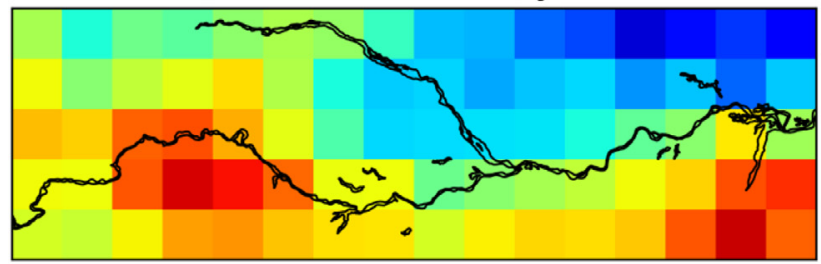

k) minimum GW anomaly 2008

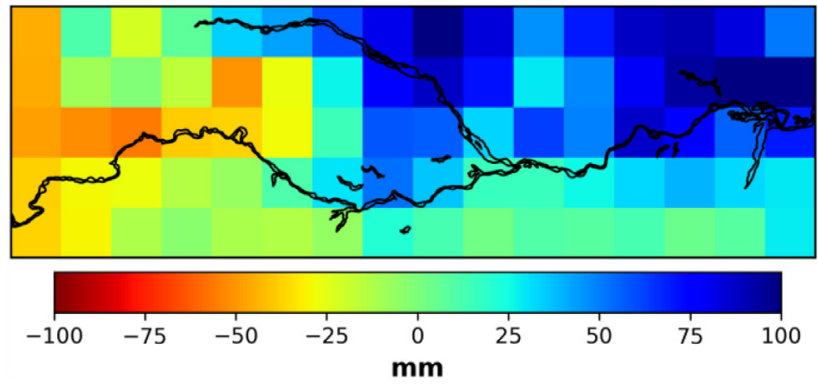

b) GWBL anomaly 2003

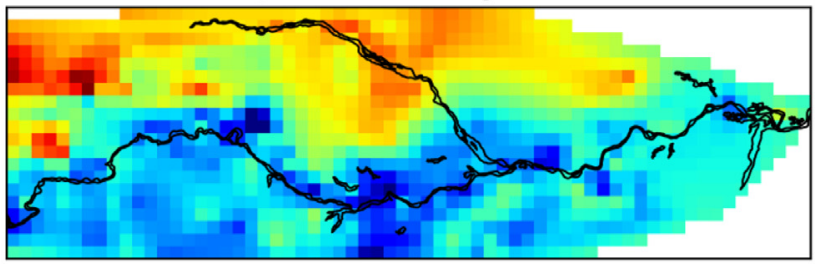

d) GWBL anomaly 2004

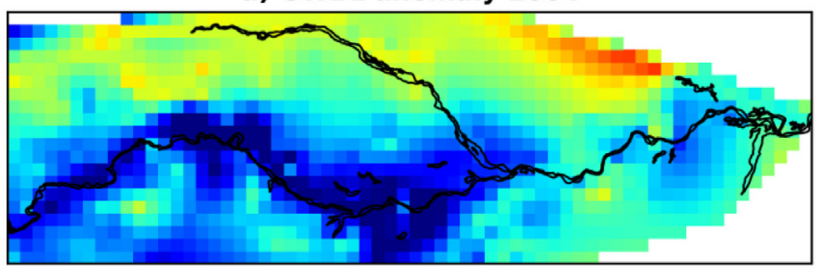

f) GWBL anomaly 2005

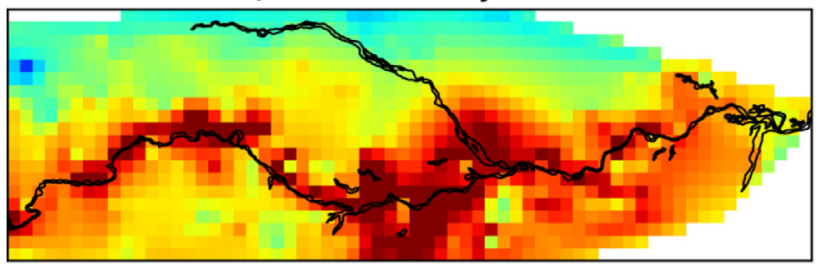

h) GWBL anomaly 2006

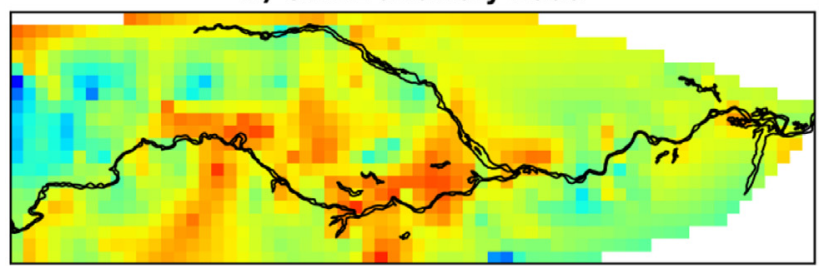

j) GWBL anomaly 2007

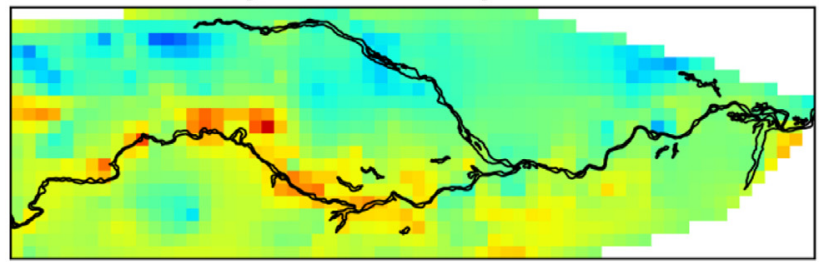

I) GWBL anomaly 2008

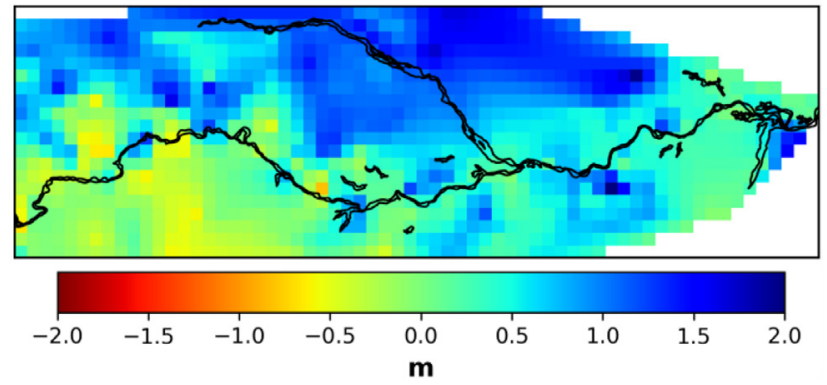

Fig 5. a) Minimum groundwater stock (GW) and groundwater base-level (GWBL) anomalies from 2003 to 2008.

GW represent around $49 \%, 27 \%$, and $24 \%$ of the seasonal TWS change of $1800 \mathrm{~km}^{3}$ respectively. Our estimates agree well with the previous studies based on model outputs (Güntner et al., 2007). Comparisons between GRACE data and model outputs showed that TWS is equally partitioned between surface and sub-surface reservoirs, and soil water as showed by Han et al. (2009) using GLDAS/NOAH, or that $S W$ and soil water $(S M+G W)$ represents $56 \%$ and $44 \%$ of $T W S$ respectively based on the large-scale hydrologic and hydrodynamic model MGB simulations (Paiva et al., 2013). Using LEAF HydroFlood, Pokhrel et al. (2013) found a larger contribution from the subsurface storage (71\%) than from $S W$ (29\%) to TWS. Using Eq. (2), we estimated the error on the $G W$ anomalies determined using the decomposition method. Using classical errors on TWS (15\%) and $S M(20 \%)$ and the maximum error on $S W$ found in Frappart et al. (2012) (17\%), we obtained an error of $18 \%$ on $G W$. 

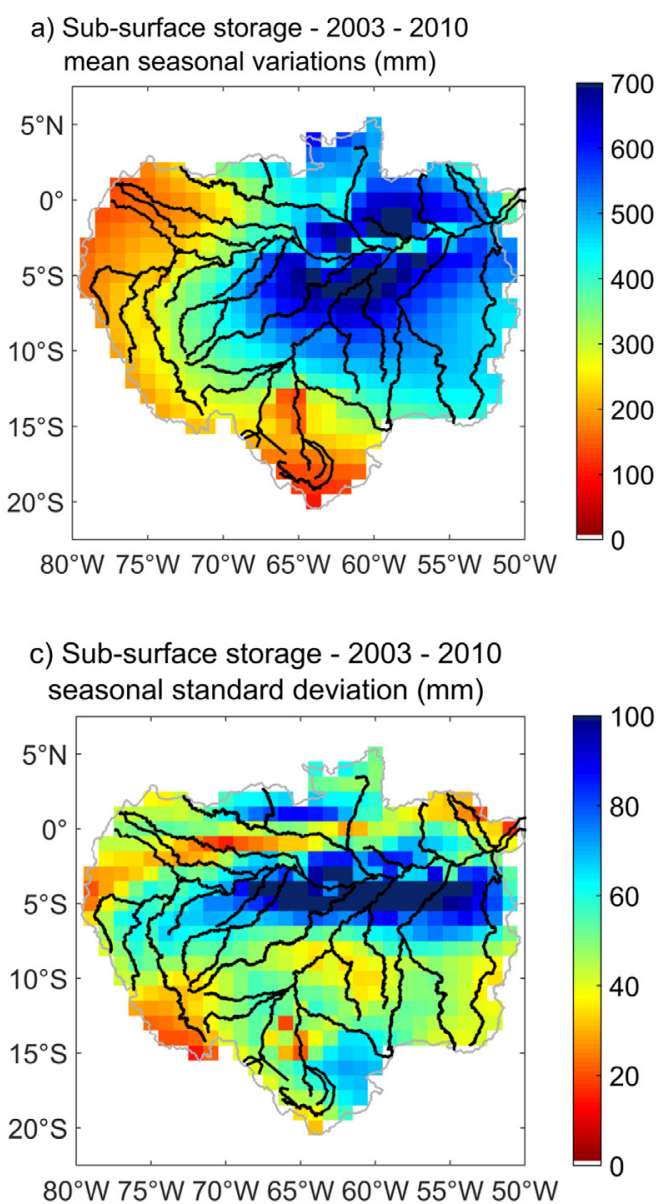

b) Groundwater storage - 2003 - 2010 mean seasonal variations $(\mathrm{mm})$

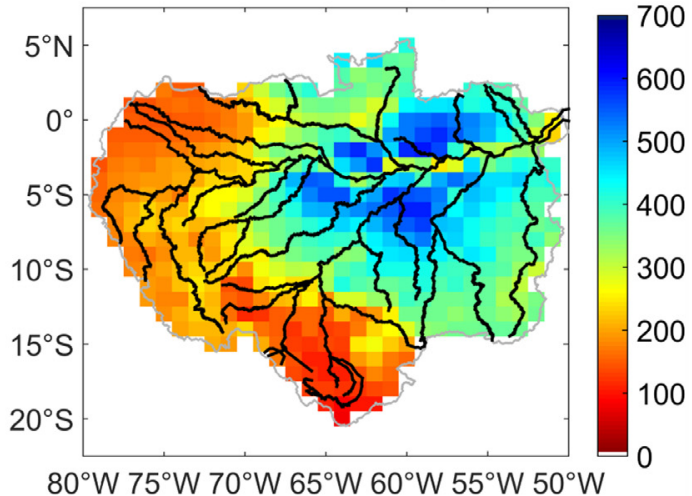

d) Groundwater storage - 2003 - 2010 seasonal standard deviation $(\mathrm{mm})$

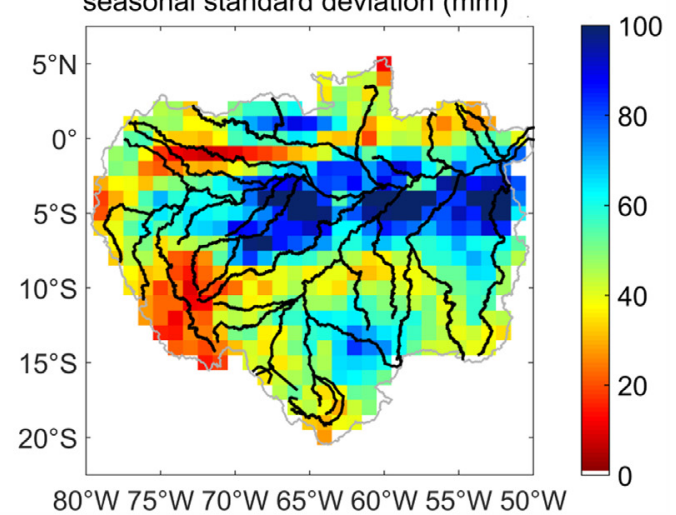

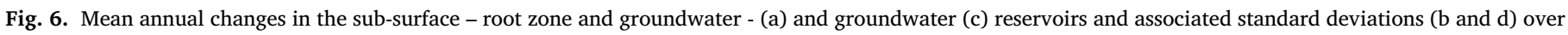
2003-2010 using the decomposition method.

At sub-basin scale, we found that the contribution of GW to TWS varies from $20 \%$ (downstream Solimões) to $70 \%$ (Xingu) consistently with what is currently known on the distribution of $S W$ (Frappart et al., 2012). These results are also in good agreement with the estimates from Pokhrel et al. (2013) and Paiva et al. (2013) for subsurface (GW+SM) storage.

Fig. 2 and Fig. S3 present the time variations of TWS, SW, SM and GW over 2003-2010 for the Amazon and its major sub-basins. In the subbasins covered with extensive floodplains (i.e., downstream Solimões, upstream Madeira, Negro, downstream Amazon, see Fig. S4 for the spatial distribution of the surface reservoir in the Amazon Basin), important time-lags can be observed between surface, shallow subsurface reservoirs and the groundwater, reaching an inverse of phase during some years. In the Negro basin, $G W$ reached their maxima (minima) between September (February) and November (March) respectively (Fig. 2c). A time-lag of three to four months is observed between the peaks of $S W$ and $G W$ in the Negro (Fig. 2c), upstream Madeira (Fig. S3c) and Downstream Amazon (Fig. S3e) basins, in agreement with smaller-scale observations (Lesack and Melack, 1995; Bonnet et al., 2008). According to these studies, extensive floodplains may delay water for several months, through storage and percolation through the vadose zone to reach the groundwater reservoir. In the case of the upstream Madeira, a decrease of $G W$ storage can be observed during the flood in 2006 and 2007, the two years presenting the largest $S W$ (and $S M$ ) storages of the study period, suggesting that $G W$ storage contributes to the flood. This endogenous inundation process was reported in several studies (Ronchail et al., 2005; Bourrel et al., 2009). After the flood, $G W$ storage is in- creasing up to similar or slightly above levels than the previous years. During the years with large flood events, $G W$ storage exhibits larger amplitude of variations. On the other hand, smaller seasonal cycle is observed for the GW storage in the Amazon (Fig. 2a) and the downstream Madeira (Fig. 2b) basins contrary to what can be observed in the other hydrological reservoirs. As previously mentioned by Miguez-Macho and Fan (2012), the seasonality may be smoothed out (e.g., the upstream Madeira and the downstream Madeira in the case of Madeira, all the tributaries of the Amazon) when spatially averaging over a large river basin. In the sub-basins (i.e., upstream Solimões, downstream Madeira, Tapajos, Xingu), the time-variations in all the hydrological reservoirs are almost in phase. Soil water storage is first replenished after rainfall, followed by deeper drainage that recharges the $G W$ storage. In Fig. 2d, the maximum of $S M$ occurs in March whereas the maximum of $G W$ is observed in April for the Tapajos. The maximum of $S W$ is reached in May corresponding to the time necessary for water to cross the whole subbasin. In the Tapajos basin, the contribution of $S W$ is low as there is no extensive floodplain along its stream. In the headwater basins (i.e., upstream Solimões Basin, Tapajos and Xingu), the seasonality of the TWS is very similar to the one of the $G W$ (Figs. S3a, 3d, and S3f).

We performed an evaluation of the $G W$ estimates from the decomposition method using sparse measurements of $G W$ levels available at several locations in the Amazon Basin (see Supplementary information, Table S1 and Fig. 1a for their locations). Except for the Asu catchment, where in situ observations and our estimates are overlapping in time between 2004 and 2005 (Fig. 3), it must be kept in mind that most in situ observations are available from 2011, so that the comparisons with our 

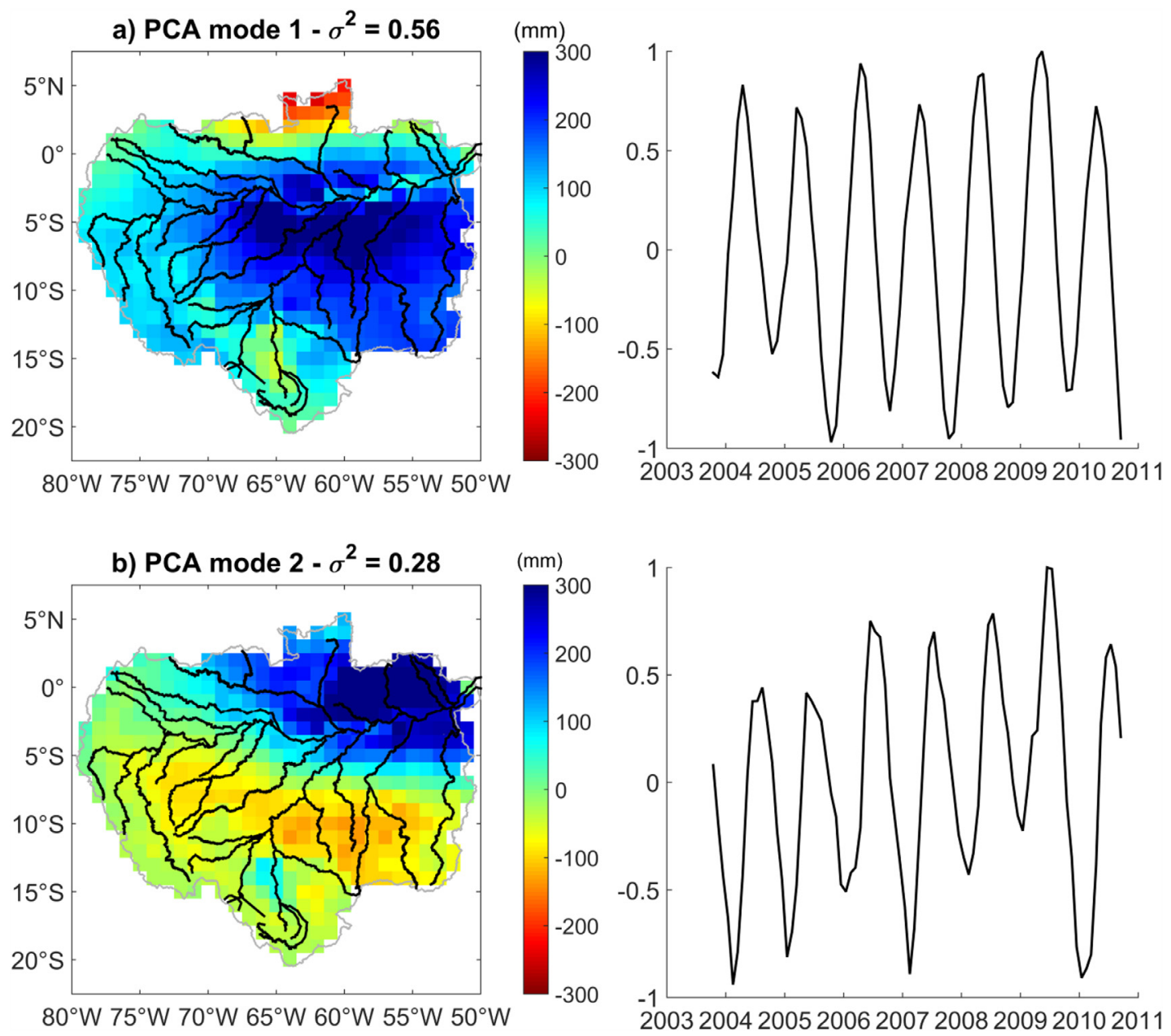

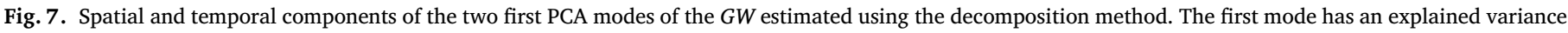
of 0.56 (a), and the second one 0.28 (b).

estimates are presented in terms of seasonal cycles with their associated standard deviation (Fig. 4 and Fig. S5).

Firstly, the time variations of $G W$ between January 2004 and November 2005 from the decomposition method exhibits an overall good agreement with the in situ measurements acquired at the Asu catchment in spite of the difference of spatial scale among them (Fig. 3). Lower/larger annual amplitude of variations is observed in 2004/2005 respectively, with a shorter peak duration observed in both datasets for 2005. In 2005, after the annual peak, the $G W$ from the decomposition method decreases much faster than in the observed dataset.

Secondly, the seasonal $G W$ variations from the decomposition method, averaged over 2003-2010, present an amplitude of around $300 \mathrm{~mm}$, with a maximum in June and a minimum in DecemberJanuary, for the gridpoints encompassing the Asu catchment $\left(60.17^{\circ} \mathrm{W}\right.$, $3.13^{\circ} \mathrm{S}$ ), north of Manaus in the Negro Basin (Tomasella et al., 2008), and the M01 site $\left(59.837^{\circ} \mathrm{W}, 3.354^{\circ} \mathrm{S}\right)$, in the downstream Madeira Basin, directly affected by the water level fluctuations of the Amazon River (Fig. 4a and b). Overall, they compare well, both in amplitude and phase, to the $G W$ variations observed at wells from the Asu catchment, recorded from August 2010 to May 2011, and from the M01 site, recorded between September 2011 and December 2012. Other comparisons were performed for sites that are more representative of the Madeira Basin, where a good drainage occurs. For these sites, there is a noticeable time-shift - in situ groundwater levels are one to two months ahead of $G W$ variations from the decomposition method-, but the amplitudes are of the same order of magnitude. Smaller differences in phase are observed for M07 $\left(61.948^{\circ} \mathrm{W}, 5.256^{\circ} \mathrm{S}\right)$ site than for M02 $\left(60.314^{\circ} \mathrm{W}\right.$, $\left.3.682^{\circ} \mathrm{S}\right), \mathrm{M} 03\left(60.726^{\circ} \mathrm{W}, 4.147^{\circ} \mathrm{S}\right)$ and $\mathrm{M} 10\left(62.92^{\circ} \mathrm{W}, 6.571^{\circ} \mathrm{S}\right)$ sites. The latter wells are affected by the presence of Janauari Lake $\left(60.032^{\circ} \mathrm{W}\right.$, $3.210^{\circ} \mathrm{S}$ ) with an area of $0.79 \mathrm{~km}^{2}$, and large flooding events during the wet season that both decrease the depth of groundwater below the terrain surface and increase the storage variations compared with the surrounding environment. Besides, it has to be kept in mind that the spatial scale between the decomposition method estimates and the in situ measurements are very different, and thatthe decomposition method is limited by the very coarse resolution of both remote sensing products $\left(0.25^{\circ}\right.$ and $2^{\circ}$ for both GIEMS-altimetry and the GRACE regional solutions respectively) and the WGHM outputs $\left(0.5^{\circ}\right)$, so that local effects monitored at GW wells are unlikely to be detected in our dataset. Nevertheless, quantitative comparisons are made between $G W$ storage from in-situ measurements and estimates from the decomposition method averaged over 2003-2010 and model outputs from WGHM and ISBA-TRIP. As already mentioned, only one in situ site (Asu catchment) provides data from January 2004 to November 2005 which overlaps both our estimates and the hydrological model outputsFor the other sites, as the time periods do not overlap, slight changes in temporality between the different sources can occur. Therefore, cross-correlations were first estimated. Using the time-delay corresponding to the maximum of correlation, RMSE (mm) and RRMSE (\%) were then computed. The amplitude ratio between the decomposition or the model outputs and the insitu measurements, computed as the ratio between the maximum amplitudes of either the decomposition method or the model outputs averaged 
Table 1

Statistical parameters resulting from the comparison between in-situ groundwater measurements and estimates from the decomposition method (GRACE), WGHM and ISBA-TRIP model outputs. RMSE and RRMSE were computed for the time-delay $(\Delta t)$ corresponding to the maximum of the cross-correlation function.

\begin{tabular}{lllllllll}
\hline \multirow{6}{*}{ GRACE } & 2004-2005 & $\begin{array}{l}\text { Average } \\
\text { Asu }\end{array}$ & Asu & M01 & M02 & M03 & M07 & M10 \\
\hline \multirow{6}{*}{ WGHM } & $R$ & 0.77 & 0.97 & 0.94 & 0.88 & 0.95 & 0.97 & 0.95 \\
& $\Delta$ t (months) & 0 & 0 & 0 & 2 & 2 & 2 & 1 \\
& RMSE (mm) & 58 & 69 & 39 & 171 & 109 & 41 & 49 \\
& RRMSE (\%) & 22 & 15 & 18 & 21 & 17 & 11 & 13 \\
& Amplitude ratio & 1.21 & 0.58 & 1.27 & 0.53 & 0.71 & 1.30 & 1.14 \\
& R & 0.79 & 0.94 & 0.97 & 0.91 & 0.99 & 0.96 & 0.92 \\
& Dt (months) & -1 & -1 & -1 & -1 & 1 & 1 & 0 \\
& RMSE (mm) & 53 & 118 & 36 & 265 & 205 & 115 & 107 \\
& RRMSE (\%) & 23 & 26 & 17 & 32 & 32 & 30 & 28 \\
& Amplitude ratio & 0.46 & 0.25 & 0.54 & 0.16 & 0.2 & 0.35 & 0.38 \\
& $R$ & 0.67 & 0.98 & 0.96 & 0.89 & 0.95 & 0.93 & 0.94 \\
& R & -2 & -2 & -2 & 0 & 0 & 1 & 0 \\
& $\Delta$ t (months) & -2 & 102 & 22 & 267 & 197 & 106 & 99 \\
& RMSE (mm) & 87 & 26 & 11 & 32 & 31 & 28 & 26 \\
& RRMSE (\%) & 34 & 0.35 & 0.77 & 0.16 & 0.24 & 0.40 & 0.43 \\
\hline
\end{tabular}

over 2004-2005 (only for Asu catcment) and 2003-2010 (all the sites). The maximum amplitude of in-situ data, was also estimated. All the results are presented in Table 1. Direct comparison over Asu catchment for 2004-2005 shows a good agreement between our estimates from the decomposition method and this very local measurement $(R=0.77$ and RRMSE $=22 \%$ ) with no time-lag. Similar results are obtained with WGHM outputs $(R=0.79$ and RRMSE $=23 \%)$ with a time-lag of one month. Lower agreement is found with ISBA-TRIP outputs. Very high correlation values, generally higher than 0.9 , are obtained for both the decomposition method and the model outputs. All the sources exhibit up to two months compared with in-situ data (between 0 and 2 months for the decomposition method, -1 and 1 for WGHM, -2 and 0 for ISBA). RRMSE are generally lower than 20\% using the decomposition method and higher than $25 \%$ for WGHM and ISBA-TRIP (except for M02 well with RRMSE of 17 and 11\% respectively). In general, amplitude ratios are also closer to 1 with the decomposition method than with the model outputs.

To be compared with GWBL anomalies, we computed the minimum $G W$ anomaly in a similar manner (minimum $G W$ for a given year minus the average $G W$ minima over 2003-2008). A positive (negative) anomaly means therefore, that the $G W$ minimum is higher (lower) this year than average over the 2003-2008 time period. As shown in Fig. 5, similar patterns are found in the minimum $G W$ and $G W B L$ anomalies at annual and interannual timescales, despite the difference in spatial resolution between the two products: $2^{\circ}$ resampled at $1^{\circ}$ for the GRACE regional solutions and hence for the $G W$ anomalies and $0.25^{\circ}$ for the groundwater base level. The dipole between drier conditions in the north and wetter in the south clearly appears on both datasets in 2003 and more clearly in 2004. The signature of the 2005 extreme drought is clearly visible in the south west of the study area, with extremely low minimum $G W$ and GWBL anomalies, followed by a progressive increase of both quantities during the three following years.

The minimum $G W$ and $G W B L$ anomalies also agree in phase (Table 2). The is on average no biases between both anomalies, except in 2005, when the minimum $G W$ anomaly occurred one month later than the GWBL. Larger phase differences are observed locally, with RMSE values of about 1.5 month. Such differences should be expected given the temporal resolution (one month) of GRACE data, and therefore of the minimum $G W$ anomaly, and the revisit time of the ENVISAT satellite (35 days). Besides, the GWBL anomaly is more prone to detect local effects, at the scale of the river, or floodplain cross-section (from 1 to $10 \mathrm{~km}$ ), than the minimum GW anomaly displaying patterns with a typical length scale of a $100 \mathrm{~km}$ or more. The 2005 bias could however be explained by the extreme conditions encountered during the drought.
Table 2

Comparison of the phase of the minimum GWS to the GWBL.

\begin{tabular}{lll}
\hline & Bias (months) & RMSE (months) \\
\hline ALL YEARS & -0.01 & 1.55 \\
2003 & 0.13 & 1.71 \\
2004 & -0.12 & 1.49 \\
2005 & 1.02 & 1.1 \\
2006 & -0.47 & 1.47 \\
2007 & -0.57 & 1.71 \\
2008 & -0.05 & 1.32 \\
\hline
\end{tabular}

Indeed, during low-water periods, the $G W$ contributes to aliment rivers, lakes and floodplains, and therefore to maintain the water-level in surface water bodies, while the GW stocks continues to drop (Lesack and Melack, 1995).The first maps of seasonal amplitude of subsurface (SM and $G W$ ) and $G W$ storages from October 2003 to September 2010, and their associated deviations are shown in Fig. 6. They exhibit quite similar spatial distributions with lower seasonal amplitude for the $G W$ component (Fig. 6a and b) but a larger deviation (Figs. 6c and d). Maps of annual amplitude and associated standard deviation are presented in Fig. S6 for SW and SM storages. The spatial patterns of seasonal groundwater changes, averaged over October 2003- September 2010, revealed that the largest storage variations (greater than $450 \mathrm{~mm}$ ) are located in central Amazonia, between $65^{\circ} \mathrm{W}$ and $55^{\circ} \mathrm{W}$, and $0^{\circ}$ and $7.5^{\circ} \mathrm{S}$, in the downstream parts of the Solimões, Negro and Madeira sub-basins, and the upstream part of the Amazon where extensive floodplains are located (Fig. 4c and Fig. S3 for the spatial distribution of the floodplains in the Amazon Basin). It corresponds to the Amazon sedimentary basin, where the Alter do Chão and Iça aquifers are located (see Fig. S6 for their locations). The largest inter-annual variability is also observed in the Amazon central corridor along the mainstem, from Tabatinga $\left(69.9^{\circ} \mathrm{W}\right.$, $4.25^{\circ} \mathrm{S}$ ) to Obidos $\left(55.68^{\circ} \mathrm{W}, 1.92^{\circ} \mathrm{S}\right)$ (Fig. 6d). It can reach $120 \mathrm{~mm}$ in the south of the Amazon mainstem and corresponds to the Alter do Chão and Iça aquifer systems. Important seasonal variations (greater than $350 \mathrm{~mm}$ ) are also present in the south (Tapajos and Xingu) and north (Negro upstream) eastern parts of the basin. For the latter one, they can be related to the Boa Vista aquifer (see Fig. S7 for its location). On the contrary, the western part of the basin is characterized by lower mean seasonal changes (less than $300 \mathrm{~mm}$ ) even in the upstream Madeira Basin (Fig. 4c). In terms of inter-annual variability, a secondary maximum, centered in $62^{\circ} \mathrm{W}$ and $15^{\circ} \mathrm{S}$, also appears and corresponds to the Parecis aquifer (Fig. $6 \mathrm{~b}$ and see Fig. $\mathrm{S} 7$ for its location), a very porous and highly productive aquifer. Our results exhibit similar patterns when 

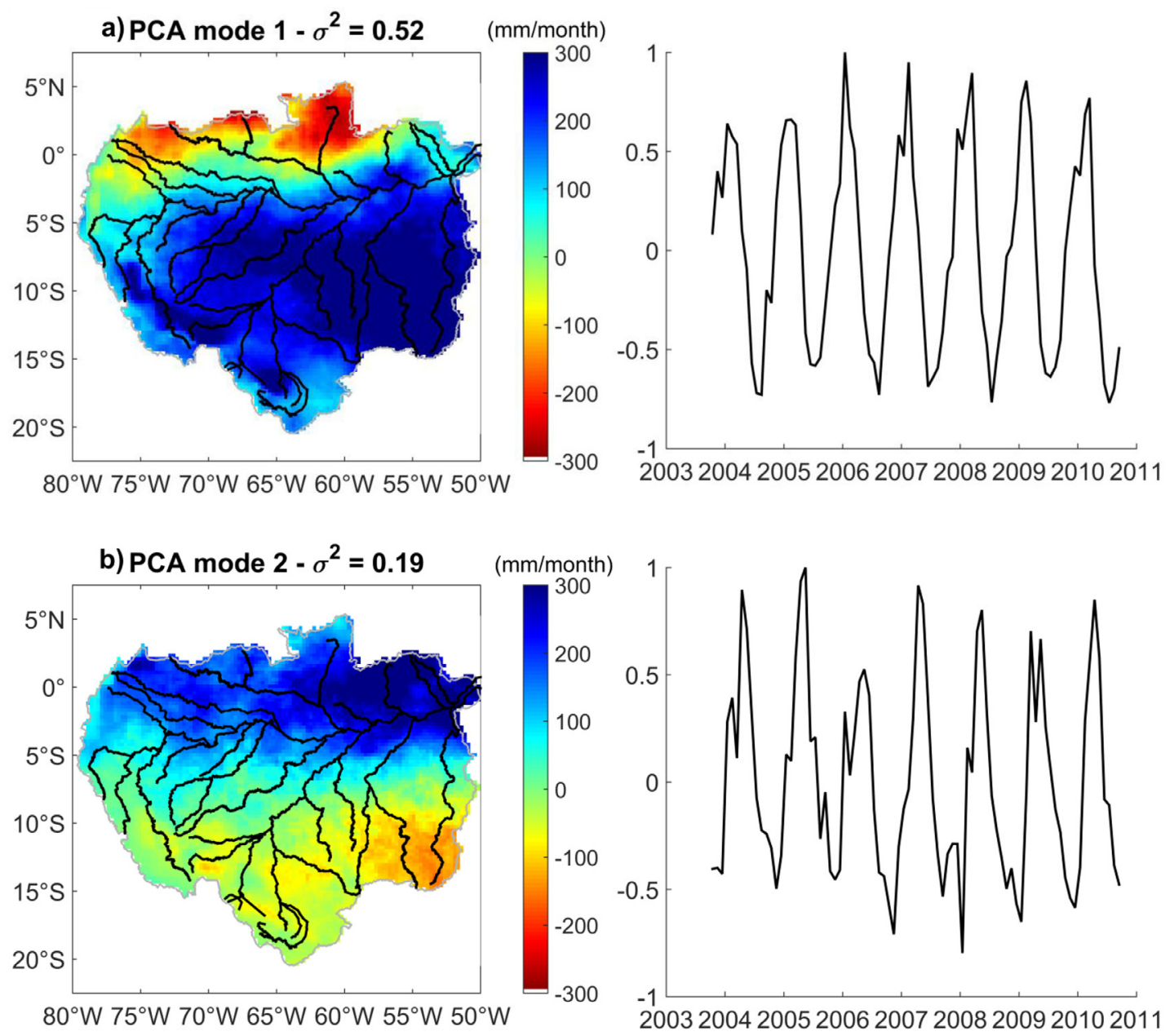

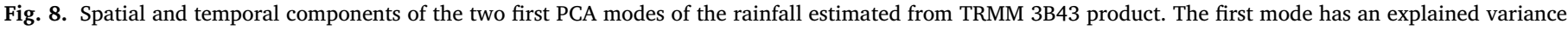
of 0.52 (a), and the second one 0.19 (b).

compared to the map of the groundwater resources of Central and South America, that provides groundwater recharge estimates, and provided by the Worldwide Hydrological Mapping and Assessment Programme (WHYMAP, http://www.whymap.org) from the Geosciences and Natural Resources (Bundesanstalt für Geowissenschaften und Rohstoffe BGR). Besides, the regions of highest variability correspond to areas where the porosity of the soil from GLHYMPS (Gleeson et al., 2013) is greater than $25 \%$. We can notice that the porosity decreases along the Amazon mainstem as does the seasonal amplitude of GW (Fig. S8a) and its inter-annual variability (Fig. S8b).

A principal component analysis (PCA) was finally performed on the temporal anomaly of Amazon $G W$ storage obtained using the decomposition method from October 2003 to September 2010. The two first modes explained around $85 \%$ of the total variance. Their spatial and temporal components are presented in Fig. 7. The first mode, that accounts for $56 \%$ of the explained variance, presents a decrease of the GW storage over the whole period in the southern part of the basin, that is especially large in the south western part of the Alter do Chão aquifer (Fig. 7a). An exceptionally low water storage can be seen in southern hemisphere spring 2005 resulting from the extreme drought of 2005 (Tomasella et al., 2011), followed by a large maximum in 2006 due to the larger than usual flood that occurred this year. Similar observations were made on the GWBL derived from radar altimetry along the central Amazon (Pfeffer et al., 2014) that showed a large negative anomaly groundwater base level in 2005 followed by a slow rise from north to south starting in 2006 .

On the one hand, positive and negative peaks are also observed in 2009 and 2010 corresponding to the exceptional flood and drought that occurred those two years respectively. As the maximum of the 2010 was recorded in October 2010, its impact on $G W$ cannot completely be observed in our dataset that stops in September 2010. On the other hand, the second mode $\left(\sigma^{2}=0.28\right)$ exhibits an increase in groundwater storage in the north eastern part of the Alter do Chão aquifer (Fig. 5b), with a large peak during the 2006 flood. This is also in good agreement with the results from Pfeffer et al. (2014) that shows an increase of GWBL from north to south. In parallel, PCA is also performed on the temporal anomaly of rainfall in the Amazon Basin. The first two modes, which spatial and temporal components are presented in Fig. 8, account for $56 \%$ and $19 \%$ of the explained variance respectively. Very similar patterns can be observed between the spatial modes of the $G W$ and rainfall anomalies, with differences that mostly occurred in the western part of the basin explained by inaccuracies of TRMM rainfall product over mountainous areas, as already reported in several studies (e.g., Mourre et al., 2016; Satgé et al., 2016; Erazo et al., 2018).

\section{Discussion and conclusion}

Differences were found in the partition of sub-surface storage in $S M$ and $G W$ components between the results presented in this study and earlier results. Compared with other studies, our results showed a lower contribution of the $S M$ to the subsurface storage. The WGHM model is one of the only global hydrological models that takes into account all the different water storage reservoirs on the continents (except ice and glaciers), with its surface reservoir containing a floodplain sub-reservoir. As a consequence, less water is attributed to SM component than in other hydrological models (see RRMSE (\%) between ISBA-TRIP and WGHM 
outputs using WGHM as the reference in Fig. S9). Very large differences can be seen over the Andean part of the basin as well as, generally, along the rivers where are located the floodplains due to very large values of $S M$ for ISBA-TRIP. This is due to i) the absence of use of stations for calibration of the ISBA-TRIP model out of Brazil and ii) the lack of a floodplain reservoir in the ISBA-TRIP model. This reinforces the choice of the WGHM model for simulating the $S M$ reservoir. On the other locations, RRMSE is generally lower than $40 \%$. The depth of the root zone in WGHM has typical values around 1 or $2 \mathrm{~m}$ and may reach $4 \mathrm{~m}$ for tropical evergreen broadleaf forest (Müller Schmied et al., 2014). But, in the Amazon Basin, the root zone can extend to depths greater than $4 \mathrm{~m}$ in the lowland tropical forests (Nepstad et al., 2004; Markewitz et al., 2010). This could explain a possible underestimation of the $S M$ component causing an overestimation of the $G W$ variations (see Table S1 presenting the depth of the water table for the wells used for comparison with our estimates). In the Negro sub-basin, root zone depths up to $5 \mathrm{~m}$ were estimated during the extreme drought of 2010. Nevertheless, in the regions where $G W$ storage variations are the largest, a good agreement was found between our estimates and in situ measurements (Fig. 3a and b).

The monthly maps of anomaly of $G W$ provide a new and unprecedented information on the dynamics of water storage in the aquifer of the Amazon Basin. They suggest that the drought of 2005 induced an inter-annual anomaly in $G W$ storage visible up to the end of the observing period in the southwest of the Alter do Chão aquifer (Fig. 5a). This supports the mechanism of persistence of rainfall deficit in the $G W$ storage (Bierkens and vand den Hurk, 2007). They also help for a better understanding of the relationship between $S W$ and $G W$ reservoirs. According to the water balance equation, changes in TWS represent, at basinscale, the difference between the rainfall, the evapotranspiration and the runoff (difference between outflow and inflow). In most of headwater catchments (i.e., upstream Solimões Basin, Tapajos, Xingu) changes in TWS against time are dominated by the GW reservoir. TWS and outflow minus inflow are well correlated (Frappart et al., 2013b). This suggests that in headwater sub-basins with no extensive floodplains, groundwater is the major contributor to discharge, confirming results from hydrological modeling (Miguez-Macho and Fan, 2012). In the other subbasins, the contribution of $G W$ to TWS is lower. $S W$ storage is in phase with TWS whereas a phase shift of several months is observed with $G W$ (Fig. 2 and Fig. S2). The time-lags observed between $S W$ and $G W$ need to be further investigated and could provide important information on the exchanges (infiltration and seep) between $G W$ and $S W$.

\section{Acknowledgments}

This work was supported by the CNES TOSCA grant "Variability of terrestrial freshwater storage in the Tropics from multisatellite observations - HyVarMultiObs" and the CNES OSTST grant "new Perspectives for higher ResolutIon Altimetry - a Multi-disciplinary approach PRIAM)". We acknowledge Bertrand Decharme for providing the ISBATRIP model output. We thank Catherine Prigent and two anonymous reviewers for their helpful comments. Results incorporated in this publication have received funding from the European Union's Horizon 2020 research and innovation programme under the Marie Sklodowska-Curie grant agreement No 706011. Data collection on IPM sites was supported by PRONEX-FAPEAM (1600/2006), Hidroveg Universal CNPq (473308/2009-6), FAPESP/FAPEM (465/2010), PPBio Manaus (CNPq 558318/2009-6), Projeto Cenarios FINEP/CNPq (52.0103/2009-2) and INCT CENBAM.

\section{Supplementary materials}

Supplementary material associated with this article can be found, in the online version, at doi:10.1016/j.advwatres.2018.12.005.

\section{References}

Alkama, R., Decharme, B., Douville, H., Becker, M., Cazenave, A., Sheffield, J., Voldoire, A., Tyteca, S., Le Moigne, P., 2010. Global evaluation of the ISBA-TRIP continental hydrological system. Part I: comparison to GRACE terrestrial water storage estimates and in situ river discharges. J. Hydrometeor. 11 (3), 583-600.

Alsdorf, D.E., Rodríguez, E., Lettenmaier, D.P, 2007. Measuring surface water from space. Rev. Geophys. 45, RG2002.

Bierkens, M.F.P., van den Hurk, B.J.J.M, 2007. Groundwater convergence as a possible mechanism for multi-year persistence in rainfall. Geophys. Res. Lett. 34, L02402.

Bonnet, M-P., Barroux, G., Martinez, J.M., Seyler, F., Moreira-Turcq, P.F., Cochonneau, G., Melack, J.M., Boaventura, G.R., Maurice-Bourgoin, L., León Hernández, J.G., Roux, E. Calmant, S., Kosuth, P., Guyot, J.L., Seyler, P., 2008. Floodplain hydrology in an Amazon floodplain lake (Lago Grande de Curuaí). J. Hydrol. 349 (1), 18-30.

Bourrel, L., Phillips, L., Moreau, S, 2009. The dynamics of floods in the Bolivian Amazon Basin. Hydrol. Process. 23, 3161-3167.

Carvalho, JS, 2012. Caracterização hidrogeológica da região norte da cidade de Manaus, com base em informações geofísicas (resistividade elétrica), geológicas e geomorfológicas. INPA-UEA, p. 87.

Chen, J.L., Wilson, C.R., Tapley, B.D., Yang, Z.L., Niu, G.Y, 2009. The 2005 drought event in the Amazon River Basin as measured by GRACE and climate models. J. Geophys. Res. 114, B05404.

Chen, J.L., Wilson, C.R., Tapley, B.D., 2010. The 2009 exceptional Amazon flood and interannual terrestrial water storage change observed by GRACE. Water Resour. Res. 46, W12526.

Decharme, B., Alkama, R., Douville, H., Becker, M., Cazenave, A, 2010. Global evaluation of the ISBA-TRIP continental hydrological system. Part II: uncertainties in river routing simulation related to flow velocity and groundwater storage. J. Hydrometeorol. $11,601-617$

Do Nascimento, N.R., Fritsch, E., Bueno, G.T., Bardy, M., Grimaldi, C., Melfi, A.J., 2008. Podzolization as a deferraltization process: dynamics and chemistry of ground and surface waters in an Acrisol - Podzol sequence of the upper Amazon basin. Eur. J. Soil Sci. 59, 911-924.

Erazo, B., Bourrel, L., Frappart, F., Chimborazo, O., Labat, D., Dominguez-Granda, L., Matamoros, D., Mejia, R, 2018. Validation of satellite estimates (Tropical Rainfall Measuring Mission, TRMM) for rainfall variability over the Pacific slope and Coast of Ecuador. Water 10 (2), 213.

Espinoza, J.C., Ronchail, J., Frappart, F., Lavado, W., Santini, W., Guyot, J-L., 2013. The major floods in the Amazonas River and tributaries (Western Amazon basin) during the 1970-2012 period: a focus on the 2012 flood. J. Hydrometeorol. 14 (3), 1000-1008.

Fan, Y., Li, H., Miguez-Macho, G, 2013. Global patterns of groundwater table depth. Science 339 (6122), 940-943.

Frappart, F., Papa, F., Güntner, A., Werth, S., Santos da Silva, J., Tomasella, J., Seyler, F., Prigent, C., Rossow, W.B., Calmant, S., Bonnet, M.-P., 2011. Satellite-based estimates of groundwater storage variations in large drainage basins with extensive floodplains. Remote Sens. Environ. 115 (6), 1588-1594.

Frappart, F., Papa, F., Santos da Silva, J., Ramillien, G., Prigent, C., Seyler, F., Calmant, S, 2012. Surface freshwater storage in the Amazon basin during the 2005 exceptional drought. Environ. Res. Lett. 7 (4), 044010.

Frappart, F., Seoane, L., Ramillien, G, 2013a. Validation of GRACE-derived water mass storage using a regional approach over South America. Remote Sens. Environ. 137, 69-83.

Frappart, F., Ramillien, G., Ronchail, J, 2013b. Terrestrial water storage variations over 2003-2010 using GRACE and TRMM observations. Int. J. Climatol. 33 (14), 3029-3046.

Frappart, F., Papa, F., Malbéteau, Y., León, J.G., Ramillien, G., Prigent, C., Seoane, L., Seyler, F., Calmant, S, 2015. Surface freshwater storage variations in the Orinoco floodplains using multi-satellite observations. Remote Sens. 7 (1), 89-110.

Frappart, F., Ramillien, G., Seoane, L., 2016. Monitoring water mass redistributions on land and polar ice sheets using the GRACE gravimetry from space mission. In: Baghdadi, N., Zribi, M. (Eds.), Land Surface Remote Sensing in Continental Hydrology. Elsevier, Amsterdam, Nederland, pp. 255-279. https://doi.org/10.1016/ B978-1-78548-104-8.50008-5.

Frappart, F., Ramillien, G, 2018. Monitoring groundwater storage changes using the Gravity Recovery and Climate Experiment (GRACE) satellite mission: a review. Remote Sens. 10 (6), 829.

Freeden, W., Schreiner, M., 2008. Spherical Functions of Mathematical Geosciences: A Scalar, Vectorial and Tensorial Setup. Springer, p. 602. pp.

Gleeson, T., Moosdorf, N., Hartmann, J., van Beek, L.P.H, 2013. A glimpse beneath earth's surface: GLobal HYdrogeological MaPS (GLHYMPS) of permeability and porosity. Geophys. Res. Lett. 41, 3891-3898.

Güntner, A., Stuck, J., Werth, S., Döll, P., Verzano, K., Merz, K, 2007. A global analysis of temporal and spatial variations in continental water storage. Water Resour. Res. 43 (5), W05416.

Han, S.-C., Kim, H., Yeo, I.-Y., Yeh, P., Oki, T., Seo, K.-W., Alsdorf, D., Luthcke, S.B., 2009. Dynamics of surface water storage in the Amazon inferred from measurements of inter-satellite distance change. Geophys. Res. Lett. 36, L09403.

Huffmann, G.J., Adler, R.F., Rudolf, B., Schneider, U., Keehn, P.R, 1995. Global precipitation estimates based on a technique for combining satellite-based estimates rain gauge analysis and NWP model precipitation information. J. Clim. 8, 1284-1295.

Huffmann, G.J., Adler, R.F., Bolvin, D.T., Gu, G., Nelkin, E.J., Bowman, K.P., Hong, Y., Stocker, E.F., Wolf, D.B, 2007. The TRMM multi-satellite precipitation analysis (TMPA): quasi-global. multi-year combined-sensor precipitation estimates at fine scale. J. Hydrometeorol. 8, 38-55. 
Jin, S.G., Feng, G.P, 2013. Large-scale variations of global groundwater from satellite gravimetry and hydrological models, 2002-2012. Global Planet. Change 106, 20-30.

Leblanc, M.J., Tregoning, P., Ramillien, G., Tweed, S.O., Fakes, A., 2009. Basin-scale, integrated observations of the early 21st century multiyear drought in southeast Australia. Water Resour. Res. 45, W04408.

Lehner, B., Grill, G, 2013. Global river hydrography and network routing: baseline data and new approaches to study the world's large river systems. Hydrol. Process. 27, 2171-2186.

Lesack, L.F., Melack, J.M, 1995. Flooding hydrology and mixture dynamics of lake water derived from multiple sources in an Amazon floodplain lake. Water Resour. Res. 31 (2), 329-345

Marengo, J., Nobre, C., Tomasella, J., Sampaio, G., Camargo, H, 2008. The drought of Amazonia in 2005. J. Clim. 21, 495-516.

Marengo, J.A., Tomasella, J., Alves, L.M., Soares, W.R., Rodriguez, D.A, 2011. The drought of 2010 in the context of historical droughts in the Amazon region. Geophys. Res. Lett. 38, L12703.

Margat, J., van de Gun, J., 2013. Groundwater Around the World: A Geographic Synopsis. Taylor \& Francis, p. 376. pp..

Markewitz, D., Devine, S., Davidson, E.A., Brando, P., Nepstad, D.C, 2010. Soil moisture depletion under simulated drought in the Amazon: impacts on deep root uptake. New Phytol. 187 (3), 592-607.

Miguez-Macho, G., Fan, Y., 2012. The role of groundwater in the Amazon water cycle: 1. Influence on seasonal streamflow, flooding and wetlands. J. Geophys. Res. Atmos. 117, D15113.

Mourre, L., Condom, T., Junquas, C., Lebel, T., Sicart, J.E., Figueroa, R., Cochachin, A., 2016. Spatio-temporal assessment of WRF, TRMM and in situ precipitation data in a tropical mountain environment (Cordillera Blanca, Peru). Hydrol. Earth Syst. Sci. 20, 125-141.

Müller Schmied, H., Eisner, S., Franz, D., Wattenbach, M., Portmann, F.T., Floerke, M., Döll, P., 2014. Sensitivity of simulated global-scale freshwater fluxes and storages to input data, hydrological model structure, human water use and calibration. Hydrol. Earth Syst. Sci. 18 (9), 3511-3538.

Nepstad, D.C., Lefebvre, P.A., Lopes da Silva, U., Tomasella, J., Schlesinger, P., Solorzano, L., Moutinho, P, Ray, D., Guerreira Benito, J, 2004. Amazon drought and its implications for forest flammability and tree growth: a basin-wide analysis. Global Change Biol. 10 (5), 704-717.

Normandin, C., Frappart, F., Diepkilé, A.T., Marieu, V., Mougin, E., Blarel, F., Lubac, B., Braquet, N., Ba, A, 2018. Evolution of the performances of radar altimetry missions from ERS-2 to Sentinel-3A over the Inner Niger Delta. Remote Sens. 10 (6), 833.

Paiva, R.C.D., Buarque, D.C., Collischonn, W., Bonnet, M.-P., Frappart, F., Calmant, S., Mendes, A.B, 2013. Largescale hydrologic and hydrodynamic modeling of the Amazon River basin. Water Resour. Res. 49 (3), 1226-1243.

Papa, F., Prigent, C., Aires, F., Jimenez, C., Rossow, W.B., Matthews, E, 2010. Interannual variability of surface water extent at global scale. J. Geophys. Res. 115, D12111.

Papa, F., Frappart, F., Güntner, A., Prigent, C., Aires, F., Rossow, W.B., Getirana, A., Maurer, R, 2013. Surface water storage and variability in the Amazon basin from multi-satellite observations, 1993-2007. J. Geophys. Res. 118 (21) 11,951-11,965.

Pfeffer, J., Seyler, F., Bonnet, M-P., Calmant, S., Frappart, F., Papa, F., Paiva, R.C.D., Satgé, F., Santos da Silva, J., 2014. Low-water maps of the groundwater table in the central Amazon by satellite altimetry. Geophys. Res. Lett. 41 (6), 1981-1987.

Pimentel, E.T., Hamza, V.M, 2012. Indications of regional scale groundwater flows in the Amazon Basins: inferences from results of geothermal studies. J. South Am. Earth Sci. 37, 214-227.

Pokhrel, Y.N., Fan, Y., Miguez-Macho, G., Yeh, P.J.-F., Han, S.-C., 2013. The role of groundwater in the Amazon water cycle: 3. Influence on terrestrial water storage computations and comparison with GRACE. J. Geophys. Res 118, 3233-3244.

Prigent, C., Papa, F., Aires, F., Rossow, W.B., Matthews, E, 2007. Global inundation dynamics inferred from multiple satellite observations, 1993-2000. J. Geophys. Res. 112, D12107.
Prigent, C., Papa, F., Aires, F., Jiménez, C., Rossow, W.B., Matthews, E, 2012. Changes in land surface water dynamics since the 1990s and relation to population pressure. Geophys. Res. Lett. 39, L08403.

Ramillien, G., Frappart, F., Cazenave, A., Güntner, A., 2005. Time variations of land water storage from the inversion of 2-years of GRACE geoids. Earth Planet. Sci. Lett. 235 (1-2), 283-301.

Ramillien, G., Biancale, R., Gratton, S., Vasseur, X., Bourgogne, S, 2011. GRACE-derived surface mass anomalies by energy integral approach, application to continental hydrology. J. Geod. 85, 313-328.

Ramillien, G., Seoane, L., Frappart, F., Biancale, R., Gratton, S., Vasseur, X., Bourgogne, S, 2012. Constrained regional recovery of continental water mass time-variations from GRACE-based geopotential anomalies over South America. Surv. Geophys. 33 (5), 887-905.

Ramillien, G., Frappart, F, Seoane, L., 2014. Application of the regional water mass variations from GRACE satellite gravimetry to large-scale water management in Africa. Remote Sens. 6 (8), 7379-7405.

Rast, M., Johannessen, J., Mauser, W, 2014. Review of understanding of Earth's hydrological cycle: observations, theory and modelling. Surv. Geophys. 35 (3), 491-513.

Roddel, M., Velicogna, I., Famiglietti, J, 2009. Satellite-based estimates of groundwater depletion in India. Nature 460, 999-1003.

Ronchail, J., Bourrel, L., Cochonneau, G., Vauchel, P., Phillips, L., Castro, A., Guyot, J.L., de Oliveira, E, 2005. Climate and inundations in the Mamoré basin (South-Western Amazon - Bolivia). J. Hydrol. 302, 223-238.

Sampson, C.C., Smith, A.M., Bates, P.D., Neal, J.C., Alfieri, L., Freer, J.E, 2015. A high-resolution global flood hazard model. Water Resour. Res. 51, 7358-7381.

Santos da Silva, J., Calmant, S., Rotuono Filho, O., Seyler, F., Cochonneau, G., Roux, E., Mansour, J.W, 2010. Water Levels in the Amazon basin derived from the ERS-2 and ENVISAT Radar Altimetry Missions. Remote Sens. Environ. 114, 2160-2181.

Satgé, F., Bonnet, M.-P., Gosset, M., Molina, J., Lima, W.H.Y., Zolá, R.P., Timouk, F., Garnier, J, 2016. Assessment of satellite rainfall products over the Andean plateau. Atmos. Res. 167, 1-14.

Seiler, K.P., Gat, J.R., 2007. Groundwater Recharge from Run-off, Infiltration and Percolation. Springer, p. 248. pp..

Seyler, F., Muller, F., Cochonneau, G., Guimarães, L., Guyot, J-L., 2009. Watershed delineation for the Amazon sub-basin system using GTOPO30 DEM and a drainage network extracted from JERS SAR images. Hydrol. Proc. 23 (22), 3173-3185.

Seoane, L., Ramillien, G., Frappart, F., Leblanc, M, 2013. Regional GRACE-based estimates of water mass variations over Australia: validation and interpretation. Hydrol. Earth Syst. Sci. 17, 4925-4939.

Shamsudduha, M., Taylor, R.G., Longuevergne, L, 2012. Monitoring groundwater storage changes in the highly seasonal humid tropics: validation of GRACE measurements in the Bengal Basin. Water Resour. Res. 48, W02508.

Tapley, B.D., Bettadpur, S., Ries, J., Thompson, P.F., Watkins, M, 2004. GRACE measurements of mass variability in the Earth system. Science 305, 503-505.

Taylor, R.G., Scanlon, B., Döll, P., Rodell, M., Van Beek, R., Wada, Y., Konikow, L, 2013. Ground water and climate change. Nat. Clim. Change 3 (4), 322.

Tian, S., Tregoning, P., Renzullo, L.J., van Dijk, A.I., Walker, J.P., Pauwels, V.R., Allgeyer, S, 2017. Improved water balance component estimates through joint assimilation of GRACE water storage and SMOS soil moisture retrievals. Water Resour. Res. 53 (3), 1820-1840.

Tomasella, J., Hodnett, M.G., Cuartas, L.A., Nobre, A.D., Waterloo, M.J., Oliveira, S.M, 2008. The water balance of an Amazonian micro-catchment: the effect of interannual variability of rainfall on hydrological behaviour. Hydrol. Processes 22, 2133-2147.

Tomasella, J., Borma, L.S., Marengo, J.A., Rodriguez, D.A., Cuartas, L.A., Nobre, C.A., Prado, M.C.R, 2011. The droughts of 1996-97 and 2004-5 in Amazonia: hydrological response in the river main-stem. Hydrol. Processes 25, 1228-1242.

Yeh, P.J.-F., Swenson, S.C., Famiglietti, J.S., Rodell, M, 2006. Remote sensing of groundwater storage changes in Illinois using the Gravity Recovery and Climate Experiment (GRACE). Water Resour. Res. 42, W12203. 